\title{
Effects of warming processes on droughts and water resources in the NW Iberian Peninsula (1930-2006)
}

\author{
Sergio M. Vicente-Serrano ${ }^{1, *}$, Juan I. López-Moreno ${ }^{1}$, Anita Drumond ${ }^{2}$, \\ Luis Gimeno ${ }^{2}$, Raquel Nieto ${ }^{2}$, Enrique Morán-Tejeda ${ }^{1}{ }^{2}$ Jorge Lorenzo-Lacruz $^{1}$, \\ Santiago Beguería ${ }^{3}$, Javier Zabalza ${ }^{1}$ \\ ${ }^{1}$ Instituto Pirenaico de Ecología, and ${ }^{3}$ Estación Experimental de Aula Dei, CSIC (Spanish National Research Council), \\ Campus de Aula Dei, PO Box 202, Zaragoza 50080, Spain \\ ${ }^{2}$ Environmental Physics Laboratory, Universidade de Vigo, Ourense 32004, Spain
}

\begin{abstract}
We analysed the evolution of drought on the NW Iberian Peninsula from 1930 to 2006, and identified differences between the effects of precipitation variability and warming processes on drought severity and surface water resources. Two drought indices were used, one based on precipitation (the standardised precipitation index, SPI) and the other based on water balance, as reflected by the difference between precipitation and potential evapotranspiration, PET (the standardised precipitation evapotranspiration index, SPEI). The results show that precipitation has increased in the region, but a significant increase has also occurred in PET. No statistically significant differences were found over the study period for the severity of drought, as assessed by both the SPI and SPEI. In addition, although in the last 3 decades the mean duration of drought episodes has increased by approximately 1 mo as a consequence of the increase of the PET rates, the differences are not statistically significant. River discharge is mainly driven by precipitation variability, whereas warming processes did not have a noticeable influence on the streamflow variability between 1930 and 2006. The implications of global warming projected by global climate models on future drought severity and the availability of water resources are highly relevant in the near future.
\end{abstract}

KEY WORDS: Temperature trends $\cdot$ Streamflow $\cdot$ Aridification $\cdot$ Standardised precipitation index SPI $\cdot$ Standardised precipitation evapotranspiration index $\cdot$ SPEI

\section{INTRODUCTION}

Drought is one of the most damaging natural hazards affecting the Iberian Peninsula, causing detrimental impacts on agriculture, water resources and ecosystems (Vicente-Serrano 2006c, López-Moreno et al. 2009, Lorenzo-Lacruz et al. 2010). There has been an increase in drought severity on the Iberian Peninsula in recent decades (Vicente-Serrano et al. 2004, Vicente-Serrano 2006a, Vicente-Serrano \& CuadratPrats 2006), mainly associated with a decrease in pre- cipitation that has affected most of the region (González-Hidalgo et al. 2009).

Global warming processes may have a notable impact on drought, increasing the severity of the episodes as a consequence of water loss by evaporation and transpiration (Dai 2011). Although precipitation is the main driver of drought conditions, recent studies have illustrated the importance of temperature in explaining recent trends in water resources (Nicholls 2004, Cai \& Cowan 2008, Gerten et al. 2008, Lorenzo-Lacruz et al. 2010) and the development of natural vegetation and 
crops (Jump et al. 2006, Andreu et al. 2007, MartínezVilalta et al. 2008, Vicente-Serrano et al. 2010a). Thus, Breshears et al. (2005) and Adams et al. (2009) coined the term 'the global warming-type drought' to describe droughts related to precipitation shortages and warmer conditions. For example, the heat wave that affected central Europe in summer 2003 showed how warming processes can dramatically increase the severity of drought (Ciais et al. 2005). On the Iberian Peninsula there has been a general temperature increase of about $1{ }^{\circ} \mathrm{C}$ during the 20th century (Brunet et al. 2006), and an increase in the frequency and intensity of heat waves (Rodríguez-Puebla et al. 2009, El Kenawy et al. 2011). It is likely that this increase has contributed to the increased drought conditions in recent decades.

Warming processes may have a negative effect on the availability of surface water resources, mostly driven by higher evapotranspiration (ET) rates. Recent temperature trends are having a notable impact on the availability of water resources. In the USA, Walter et al. (2004) quantified the warming effect by means of catchment balances in areas characterised by low anthropogenic perturbation, and reported an increase of water losses by evapotranspiration from 1950 onwards. Similar results have also been presented by Yulianti \& Burn (1998) for Canada and by Lespinas et al. (2009) for the south of France.

Climate change scenarios predict a $15 \%$ decrease in precipitation and a large increase in temperature for the 21st century in southern Europe (Giorgi et al. 2004, Giorgi 2006), which will drive a large increase in the frequency and magnitude of drought episodes (Blenkinsop \& Fowler 2007, Weiß et al. 2007). The frequency and severity of droughts will probably increase during the 21st century on the Iberian Peninsula (Sheffield \& Wood 2007), and it will cause a notable decrease in the availability of water resources (Lehner et al. 2006, Feyen \& Dankers 2009). In addition, the temperature increase observed in recent decades may already have increased drought severity and the availability of water resources. The objective of the present study of the NW Iberian Peninsula was to quantify and statistically analyse drought indicators, to assess whether the observed temperature increase, which drives higher ET rates, is having a marked influence on the characteristics of droughts in the region and whether water resources are changing in response to the warming processes.

\section{METHODS}

To quantify the evolution of drought for the NW Iberian Peninsula we used 2 drought indices: (1) The standardised precipitation index (SPI), which is based on precipitation data (McKee et al. 1993, Guttman 1999,
Hayes et al. 1999, Vicente-Serrano 2006b). This index is obtained in standardised units ( $z$-scores) that are comparable among seasons. The SPI enables calculation of estimates of the duration, magnitude and intensity of drought (e.g. Vicente-Serrano et al. 2004). (2) The standardised precipitation evapotranspiration index (SPEI) (Vicente-Serrano et al. 2010b), which takes into account both precipitation and ET demand of the atmosphere. For this index a simple water balance is calculated as the difference between monthly precipitation and the potential evapotranspiration (PET). The difference series are then transformed to $z$-scores, as for the SPEI. We calculated the PET from the Hargreaves equation (Hargreaves \& Samani 1985), using monthly averages of daily maximum and minimum temperature data and the potential incoming solar radiation. This method is recommended when the required parameters to apply the Penman-Monteith equation are not available (Droogers \& Allen 2002). In addition, some experimental studies have showed similar PET estimations by means of the Penman-Monteith and Hargreaves methods in Spain (Martínez-Cob 2002, López-Urrea et al. 2006, Gavilán et al. 2008, Vanderlinden et al. 2008, LópezMoreno et al. 2009).

The objective of using these 2 indicators was to enable comparison of drought evolution based only on assessment of precipitation with that based on the combined effects of precipitation and ET. Both indices where obtained using the same log-logistic probability distribution, which shows a very close fit to the series of differences between precipitation and ET (VicenteSerrano et al. 2010c), and also to the monthly precipitation records. Use of the same probability distribution enabled accurate comparisons among the series of the 2 indicators, ensuring that any differences between the series were only related to the impact of temperature on drought conditions, and not to the method used for calculation. Both the SPI and SPEI can be obtained at different time scales, which is very useful for monitoring drought impacts on natural and socioeconomic systems (e.g. Ji \& Peters 2003, Vicente-Serrano \& LópezMoreno 2005, Lorenzo-Lacruz et al. 2010). Examples for the meaning of the different drought time scales can be found in Hayes et al. (1999), Vicente-Serrano (2006b) and Vicente-Serrano et al. (2010b). In the present study we used the time scale of 12 mo for the comparison between both drought indices, since the use of more time scales would be redundant. Nevertheless, to correlate with river discharge data (see below) we also used time scales from 1 to $24 \mathrm{mo}$, since the optimal time scale may vary notably among different hydrological systems (Vicente-Serrano \& López-Moreno 2005, Lorenzo-Lacruz et al. 2010).

The SPI and SPEI were calculated using the Climatic Research Unit (CRU) TS3 dataset (available at http:// 
badc.nerc.ac.uk/data/cru/), with a spatial resolution of $0.5^{\circ}$. In the CRU TS3, after the creation of high-resolution grids, the homogeneity of the precipitation time series was tested by means of a procedure that includes iterative checking, the creation of reference series by means of a selection of neighbours, the completion of station records and the correction of inhomogeneities. Details on the quality of dataset creation can be consulted in Mitchell \& Jones (2005). For the period 1930-2006 the study region was covered by 23 grid boxes. The 2 drought indices were calculated using these time series and a regional series for the entire NW Iberian Peninsula, which was obtained from the average values of precipitation and PET from the 23 grid boxes.

To assess the possible impact of warming processes on surface water resources, we used monthly river discharges (in $\mathrm{hm}^{3}$ ) from the gauging station of Crecente in the Miño River (see Fig. 3). This is a unique station with a long and reliable time series in the study area that records the flows generated in the region. There were also other stations available, but they were located near the mouth of the Douro River, which receives flows from a large drainage basin mostly outside the study area. Details of the hydrological data used can be found in Lorenzo-Lacruz et al. (2011). To determine the possible impact of warming on the water resources, we used 2 different approaches. On the one hand, we first transformed monthly river discharges to standardised streamflows, by means of the calculation of an optimal standardised streamflow index (SSI) (Vicente-Serrano et al. 2011). A correlation analysis was applied using the SSI and the average SPI and SPEI for the entire drainage basin for the Crecente station, in order to study to what extent the streamflow variability is related to the SPI or SPEI. The analysis was conducted using different SPI/SPEI time scales, since, a priori we do not know which would be the most suitable in the case of the Miño River. This analysis isolates the effect of warming processes, since the difference in the explained variance by SPI or SPEI will be due to the evolution of PET.

On the other hand, and following the approach applied by Walter et al. (2004), we obtained the relationship between annual precipitation, for the entire drainage catchment, and annual discharge. This was assessed by means of a linear regression model in which precipitation was the independent variable and streamflow the dependent variable. The residuals from the model (observed streamflow-predicted streamflow) were related to PET evolution. Following this approach, Lespinas et al. (2009) found a significant impact of warming processes on surface water resources in the south of France.

\section{RESULTS}

Fig. 1 shows the evolution of the 12 mo SPI and SPEI for the NW Iberian region, and also shows the evolution of the difference between the 2 indices (SPI-SPEI). The evolution of each series was very similar, and both detected the main drought episodes in the decades of 1940, 1950, 1990 and 2000, suggesting a high degree of similarity between the 2 series. The coefficient of correlation among them is 0.99. However, calculation of SPI-SPEI identified a temporal pattern with positive differences at the beginning of the study period and negative differences at the end. Thus, there was a difference between the SPI and the SPEI of about +0.2 standard deviations for the decades of 1990 and 2000, i.e. the SPEI shows an increase in the severity of drought compared with the SPI, because of the increased PET. The figure also shows the SSI for the Crecente station from 1945 to 2005. The series shows a higher temporal frequency than that observed for the 12 mo SPI and SPEI, but the main drought periods are also observed, mainly in the decades of 1940 and 1950. However, some high-intensity drought episodes were also recorded in the decades of 1980, 1990 and 2000.

Fig. 2 shows the evolution of annual precipitation and annual PET in the NW Iberian region from 1930 to 2006. These 2 variables showed a significant positive trend (Rho-Spearman test, $\mathrm{p}<0.05$ ). Thus, precipitation increased by $20.7 \mathrm{~mm}$ decade $^{-1}$, whereas PET increased by $4.2 \mathrm{~mm}$ decade ${ }^{-1}$. When the same analysis was applied to the annual values of both drought indices (December values, which summarise the annual drought conditions), the SPEI showed an increase of 0.07 standard deviations decade ${ }^{-1}$, which was less than that found for the SPI (0.09 standard deviations decade $^{-1}$ ). Nevertheless, neither annual drought indicator showed a significant trend $(p=0.052$ and $p=0.10$, for the SPI and SPEI, respectively).

Fig. 3 shows the spatial distribution of the trends in the annual difference between the SPEI and SPI, and the annual temperature and annual precipitation. Trends were analysed by means of Rho-Spearman's rank correlation test, because it is less affected than other tests by the presence of outliers and nonnormality of the series (Lanzante 1996). The trend is obtained by means of the non-parametric correlation between the series of years and the annual series of the 3 variables (SPI-SPEI difference, precipitation and temperature). Statistically significant trends were defined as $\mathrm{p}<0.05$. The trend in the difference between the SPEI and SPI was negative and significant in all $0.5^{\circ} \times 0.5^{\circ}$ pixels of the study area $(\mathrm{p}<0.05)$. The strongest trends were found in the eastern inland areas, which was consistent with the regions in which the positive trend of the PET was stronger. In contrast, 

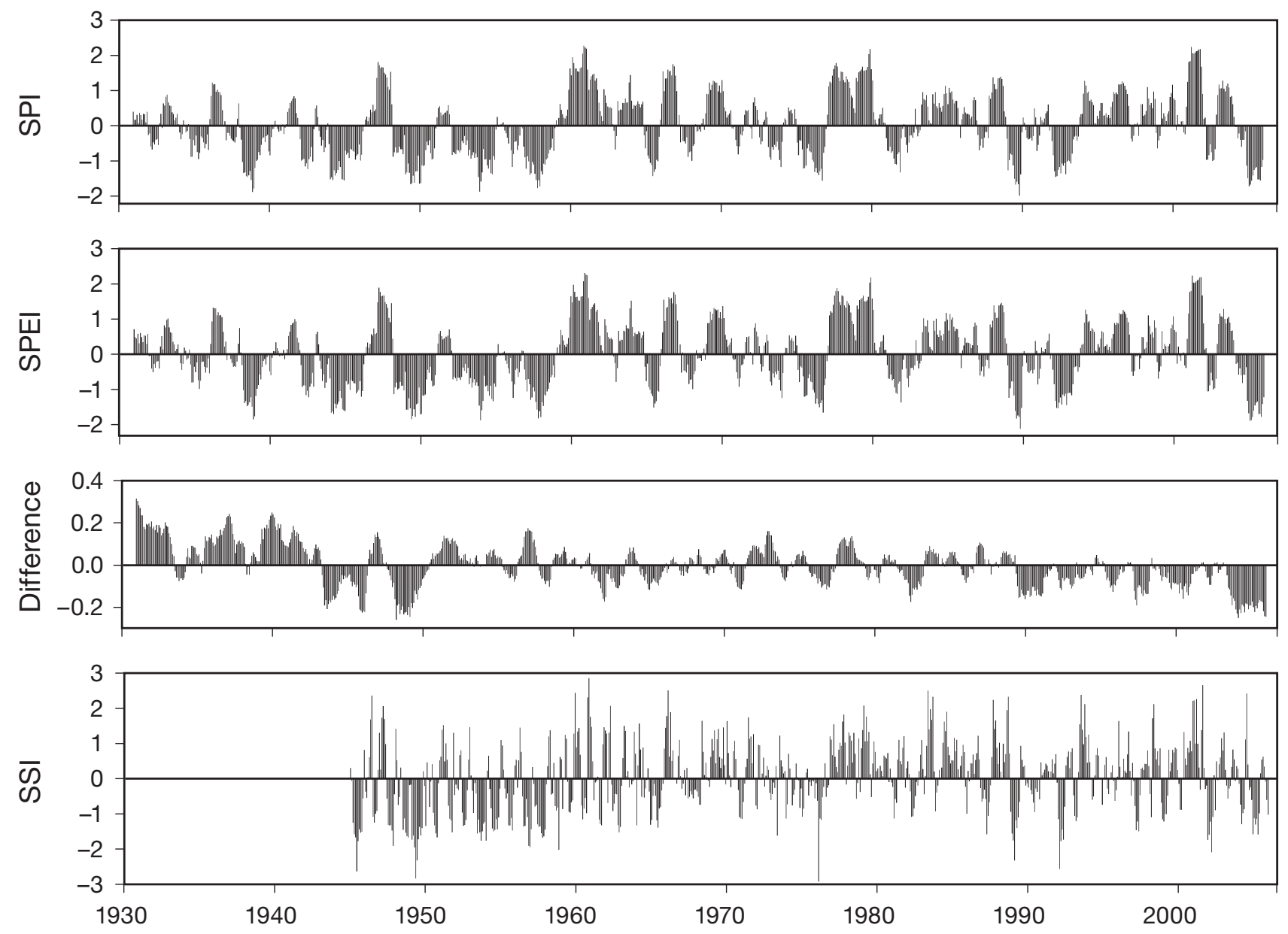

Fig. 1. Standardised precipitation index (SPI) and standardised precipitation evapotranspiration index (SPEI) from the regional series for NW Iberia. The difference between the 2 indices (SPEI and SPI) and the standardised streamflow index (SSI) for the Crecente station (Miño River) are also shown

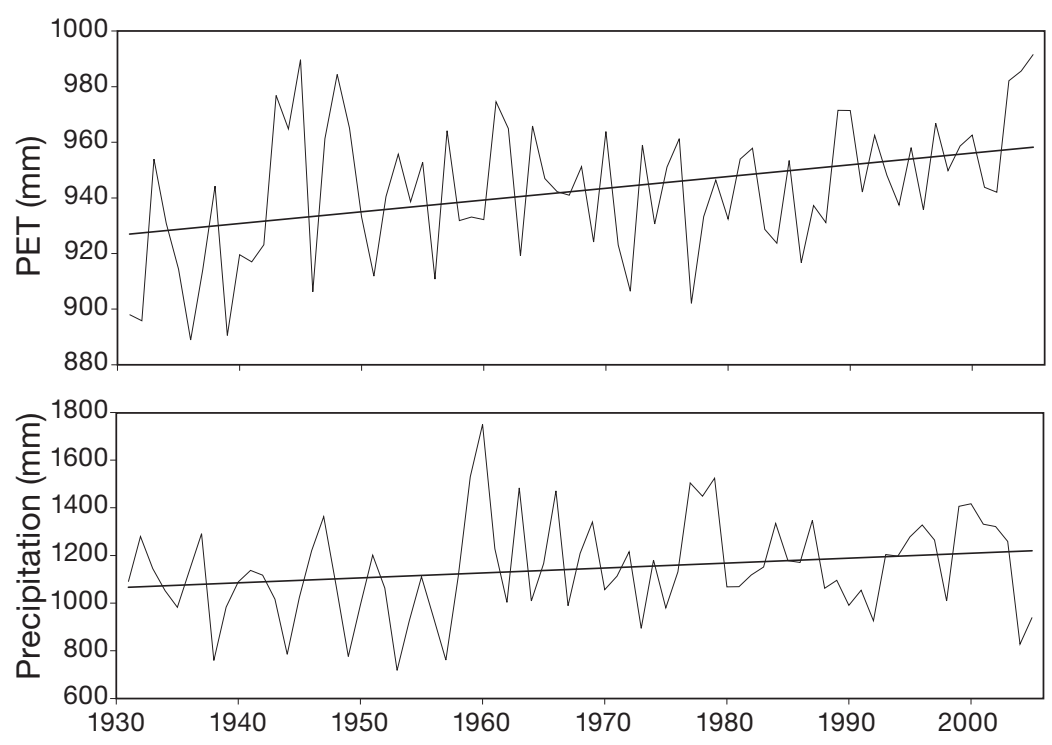

Fig. 2. Evolution of annual potential evapotranspiration (PET) and precipitation for NW Iberia the spatial pattern of precipitation did not appear to explain the trend toward dryer conditions, given that the calculation of both indicators takes this variable into account.

Based on run theory (Yevjevich 1967), we determined the individual drought episodes from the SPEI and SPI series using a threshold of 0 , which represents $50 \%$ of the probability distribution of the standardised variable, considering that all the negative values relate to dry conditions. We then determined the duration and magnitude of each drought event (Dracup et al. 1980): the duration is the number of consecutive months with values $<0$ and the sum of the index values is the drought magnitude. We focused on the 1980-2006 period, during which the 


\section{Trend SPEI-SPI}
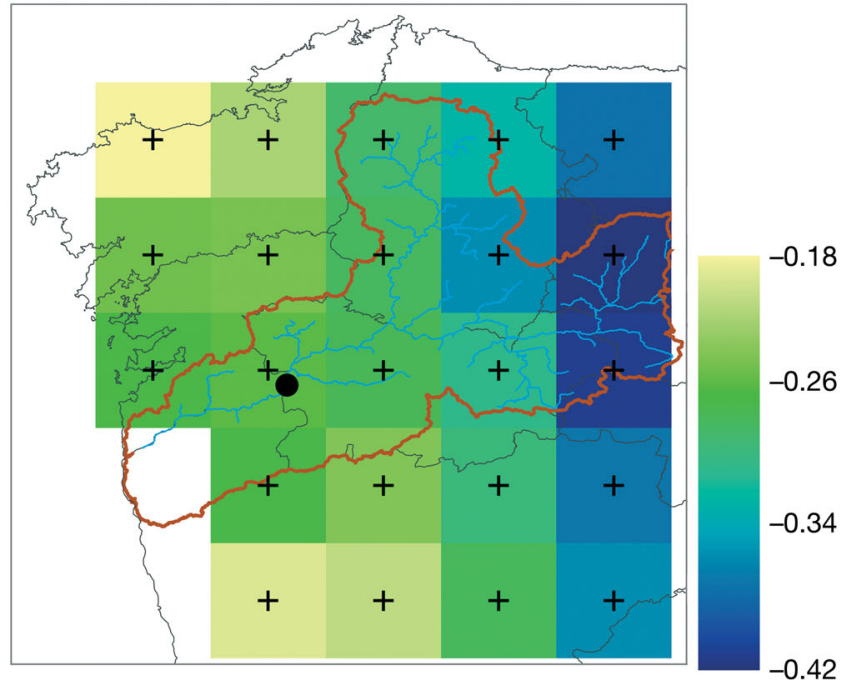

Trend Precipitation

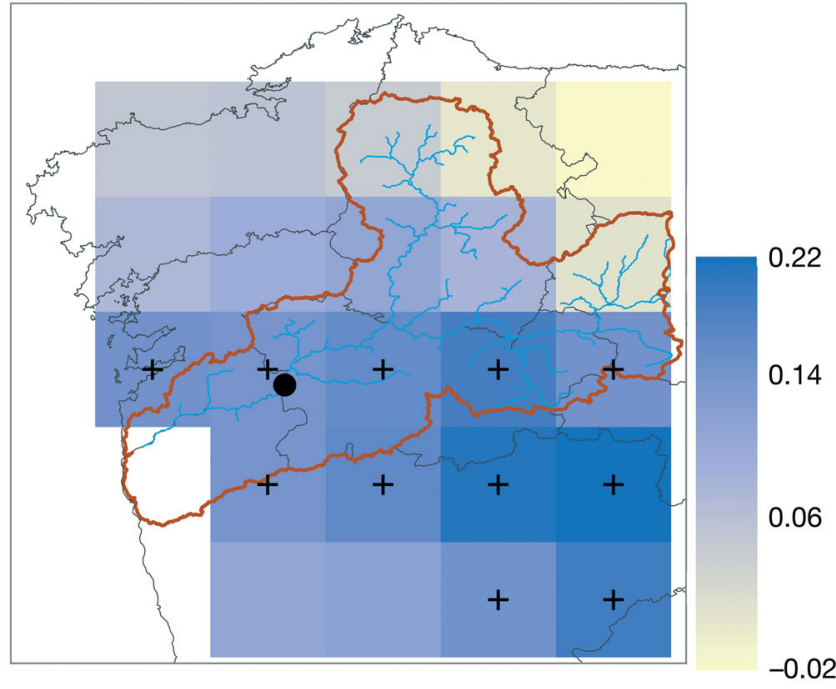

differences between the SPI and SPEI were most evident, and we compared the pattern with the initial 25 yr (1930-1955). For the 1980-2006 period, the SPI and SPEI series show a similar number of drought episodes (18 and 17, respectively). The average duration for the SPI-based drought episodes was $7.05 \mathrm{mo}$, but for the SPEI it was 7.94 mo. The average magnitudes were 5.03 and 6.0 for the SPI and SPEI series, respectively. These numbers are much lower than the averages for the 1930-1955 period (12.3 and 13.6 mo duration, and 9.3 and 10.6 magnitude, for the SPI and SPEI, respectively). Fig. 4 shows the duration and magnitude of the drought events recorded between 1930 and 1955 and between 1980 and 2006 from the 2 series. Drought severity decreased, in terms of both duration and magnitude, between the first and second time

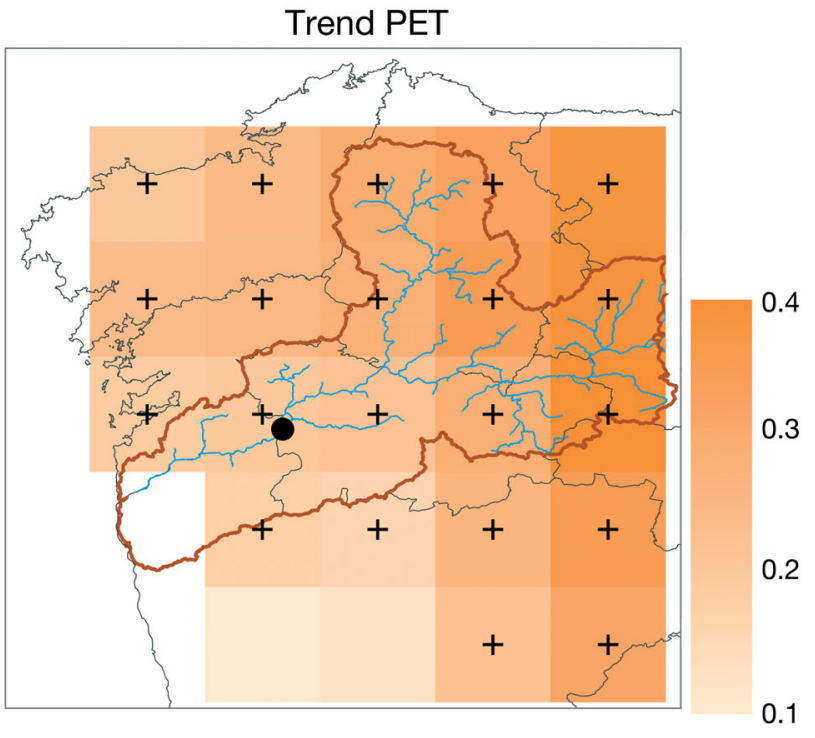

Fig. 3. Spatial distribution of annual trends: difference between standardised precipitation index (SPI) and standardised precipitation evapotranspiration index (SPEI), potential evapotranspiration (PET) and precipitation. $+\mathrm{p}<0.05$. Units are Rho-Spearman correlation coefficients. Limits of the grid boxes are: $41.25-43.25^{\circ} \mathrm{N}$ and $8.75-6.75^{\circ} \mathrm{W}$. The gauging station of Crecente (-) and the Miño drainage basin (red perimeter) are also shown

period. For the 1980-2006 period, drought severity was higher for the SPEI, but the difference between the 2 indices was low, and ANOVA indicated no statistically significant differences between the average drought duration and magnitude determined from the SPI versus the SPEI series during that period. This indicates that trends in PET in the region have affected drought severity in the last 8 decades, but the changes in drought duration and magnitude have not been statistically significant.

The previous results are in agreement with the observed pattern from the analysis of surface water resources. Fig. 5A shows the correlation coefficients obtained between the SSI at Crecente and the 1 to 24 mo SPI and SPEI for the drainage basin. The highest correlations are found at the time scales of 3 to 8 mo for both the SPEI and the SPI. Correlations are slightly higher for the SPEI, which suggests that PET explains some of the variability in the SSI. However, the difference is so small $(<0.02$ of the coefficient of correlation) that most of the SSI variability appears to be driven by precipitation. This can be confirmed by an annual statistical precipitation/discharge model. Fig. 5B shows the annual river discharge at the station of Crecente and the average annual precipitation for its drainage basin. There is a high similarity in the evolution of both series. The linear regression model based on precipita- 

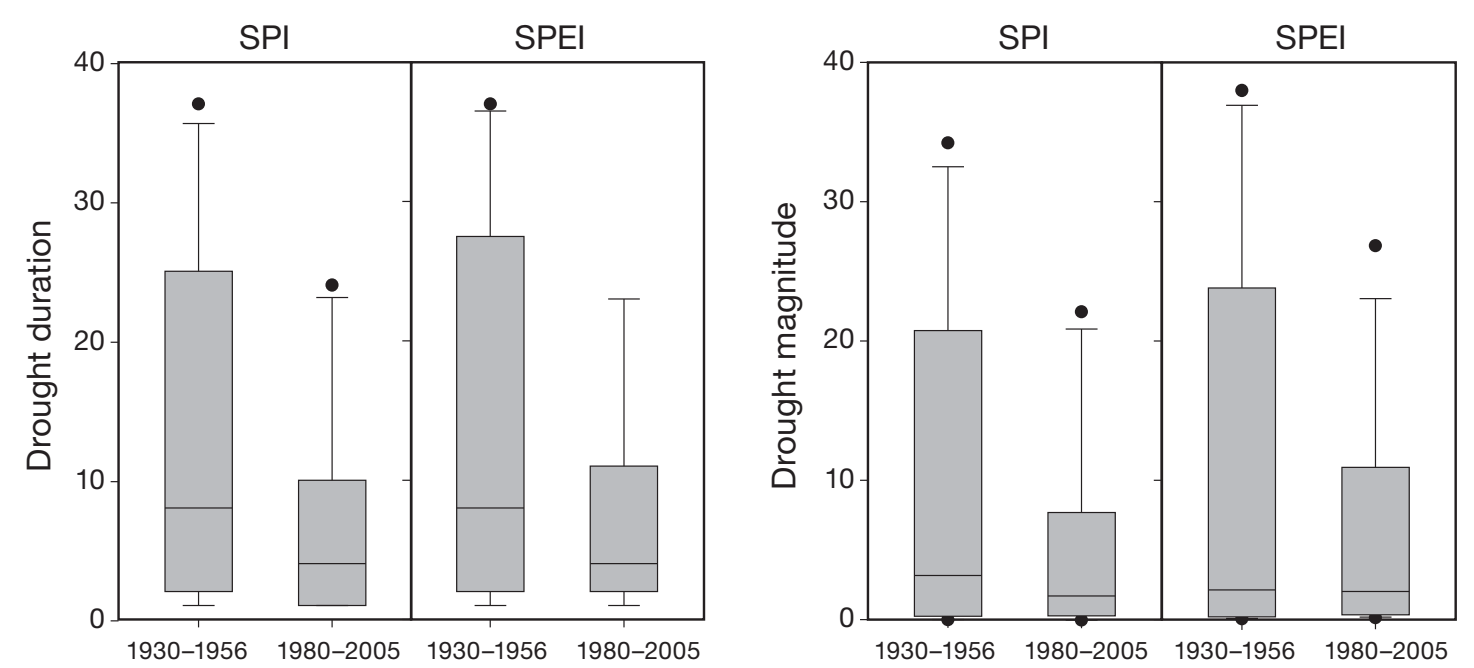

Fig. 4. Duration and magnitude of drought for the standardised precipitation index (SPI) and standardised precipitation evapotranspiration index (SPEI) series in the periods 1930-1956 and 1980-2006

tion explains $61.6 \%$ of the annual discharge variability. We tried to include the PET in the model by means of a stepwise multiple regression method, but the inclusion of this variable did not reach the required significance threshold. Fig. 5C confirms that ET processes do not significantly affect the availability of surface water resources in NW Iberia. The figure shows evolution of the residuals from the annual precipitation/discharge model and evolution of the PET for the Crecente drainage basin. The correlation between both series is low $(\mathrm{R}=0.16)$ and non-significant, showing the availability of surface water resources has not been highly affected by the PET increase observed during the last decades.
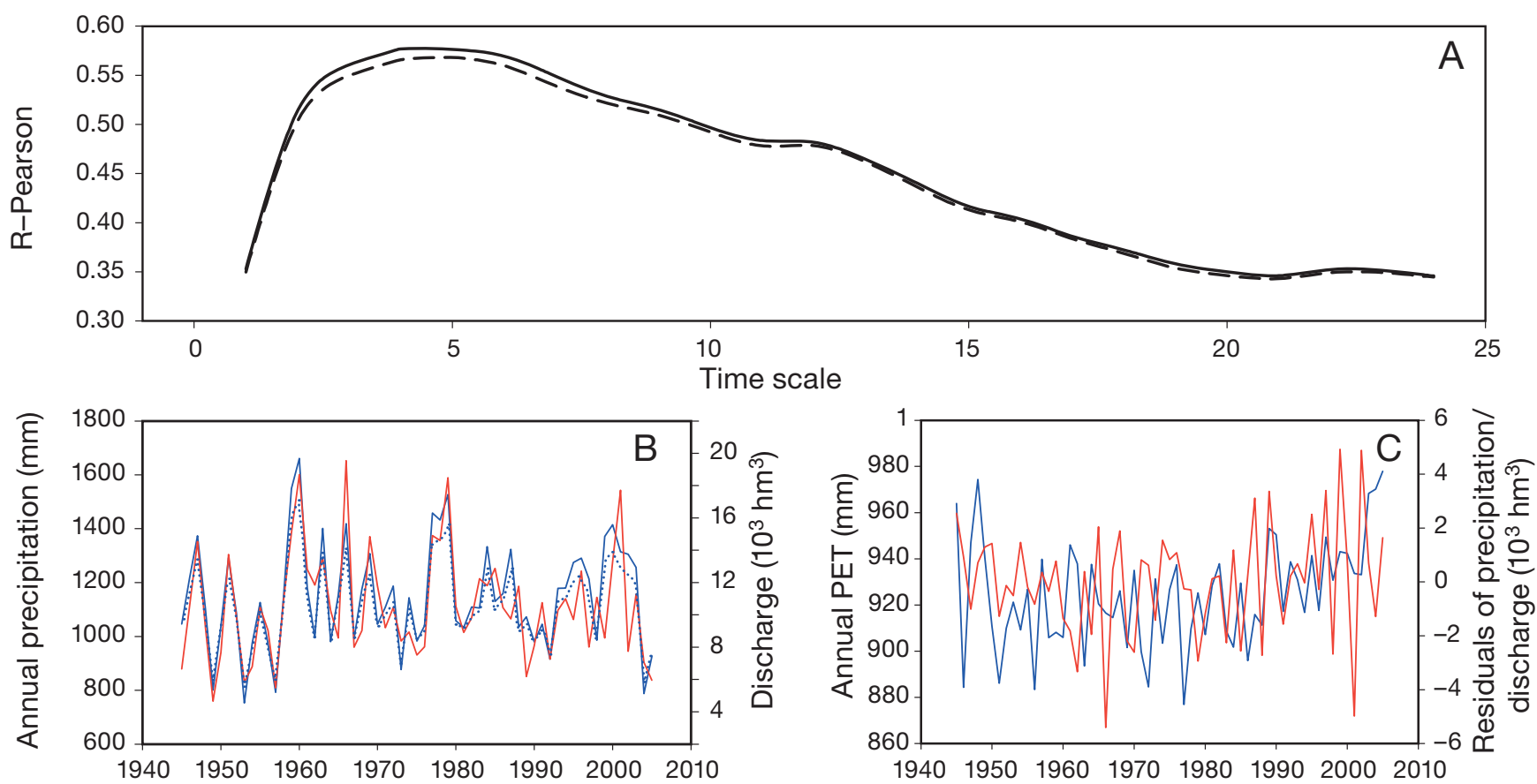

Fig. 5. (A) Correlation between the standardised streamflow index at Crecente and the 1 to 24 mo standardised precipitation index (SPI) and standardised precipitation evapotranspiration index (SPEI) for its drainage basin. (B) Evolution of the annual discharge at the station of Crecente (red line) and the average annual precipitation for its drainage basin (blue line). Dotted line shows the discharge statistical model based on precipitation data. (C) Evolution of the residuals from the annual precipitation/ discharge model (red line) and the evolution of the potential evapotranspiration (PET) for the Crecente drainage basin (blue line) 


\section{DISCUSSION AND CONCLUSIONS}

The present study investigated drought on the NW Iberian Peninsula using the SPI and SPEI. The series of both indices showed similar evolution and identified the main drought episodes that affected this region between 1930 and 2006 (mainly in the decades of 1940, 1950, 1990 and 2000). The results also indicated that droughts did not increase between 1930 and 2006, in agreement Moreira et al. (2006, 2008). This contrasts with the general trends found in other Iberian regions, in which the duration and magnitude of drought have increased (Vicente-Serrano 2006a). On a regional scale, there is evidence of a significant increase in the severity of drought in the Ebro basin (Vicente-Serrano \& Cuadrat-Prats 2006, Vicente-Serrano \& López-Moreno 2006), some areas of the Valencia region (Vicente-Serrano et al. 2004) and the Tagus basin (Lorenzo-Lacruz et al. 2010), with implications on the availability of water resources (Hisdal et al. 2001, Lorenzo-Lacruz et al. 2010) and the management of drought episodes (López-Moreno et al. 2009b). Sousa et al. (2010), using the Palmer Drought Severity Index, have also shown that NW Iberia is an exception to the predominant trend in the 20th century towards drier conditions, which has been recorded for most of the western Mediterranean.

In the NW Iberian region, calculation of the difference between the 2 indices used (SPEI-SPI) indicated more negative values in recent decades. Given that this may be related to the evolution of PET processes, our data suggest that global warming is influencing the evolution of drought in the region. Thus, the significant negative trend in the difference between the 2 indices suggests that the SPEI is detecting drier conditions. As the calculation procedure was the same for both indices, this demonstrates that the observed trends in PET (which are related to warming processes) have contributed to the intensification of drought conditions in recent decades. Various studies have demonstrated the importance of PET in explaining soil moisture variability. For example, Syed et al. (2008) showed that ET is the most significant variable explaining water storage variability at mid-latitudes. Similarly, Hu \& Willson (2000) demonstrated that ET plays a major role in drought variability quantified using drought indices, and that this is comparable to the effect of precipitation. Soil water losses due to ET also affect runoff, which affects river discharges and groundwater stores. Moreover, PET can cause large losses from water bodies including reservoirs (Wafa \& Labib 1973, Snoussi et al. 2002).

The difference between the 2 indicators suggests that the SPEI has recorded the occurrence of dryer con- ditions in recent decades, but the severity of the drought episodes has not increased significantly as a consequence of global warming processes.

In the NW Iberian region, it is likely that the high level of precipitation that characterises the region is reducing the influence of ET on drought severity. Moreover, the large increase in annual precipitation that has occurred since the decade of 1930 (20.7 mm decade $^{-1}$ ) substantially exceeds the observed increase of PET (4.2 mm decade ${ }^{-1}$ ), suggesting that the effect of precipitation on drought conditions has been greater than that of PET. This has been confirmed through the analysis of river discharge records for the Miño basin, which show that the interannual variability in surface water resources is mainly driven by precipitation variability, and, although better correlations have been found between SSI and SPEI in relation to the SPI series, the difference is too small to represent a real impact of the warming processes.

Current climate models indicate that a large increase in temperature will occur in southern Europe in the future. Based on the IPCC emissions scenario A1B, 9 general circulation models predict a temperature increase of 2 to $3^{\circ} \mathrm{C}$ for the period 2040-2070, relative to 1960-1990 (García-Ruiz et al. 2011). Such a change could exacerbate drought conditions much more than a simple decrease in precipitation. Dubrovsky et al. (2008) and Vicente-Serrano et al. (2010b) demonstrated that a temperature increase of 2 to $4^{\circ} \mathrm{C}$ in the 21st century could increase drought severity more than that expected on the basis of the projected decrease in precipitation in southern Europe. Recent models predict a notable decrease in water resources across southern Europe and the Iberian Peninsula. Mariotti et al. (2008) have predicted a decrease of $20 \%$ by the end of the 21 st century under the A1B scenario, and Lehner et al. (2006) suggested that, in southern Europe, the drought events that occur approximately every $100 \mathrm{yr}$ may change to a future frequency of 10 to $70 \mathrm{yr}$ around 2070, warming being one of the key processes in such a change (Mimikou et al. 1991). Furthermore, the influence of warming processes on water resources has already been demonstrated in some precipitation-limited environments. Cai \& Cowan (2008) showed a direct relationship between the increase of temperature and the decrease of river flow (about $15 \%$ for $1{ }^{\circ} \mathrm{C}$ of warming) in southern Australia, and, recently, Liang et al. (2010) showed that discharge is better correlated with the temperature trend than with precipitation, indicating an intensification of ET processes.

It is difficult to assess how the multiplicity of mechanisms involved will affect future drought conditions. For example, factors such as surface net solar radiation, humidity and wind speed could also change 
notably and, thus, alter the future response of ET processes to temperature (Dai 2011). Furthermore, changes in precipitation intensity could affect the runoff to precipitation ratio, which could, in turn, alter soil-water balances and hydrological regimes even if precipitation were to remain constant. In addition, part of the projected increase in temperature over the Mediterranean region could be caused by increased drought, which shifts the soil and vegetation temperature, the evaporation and transpiration processes and ultimately the radiation balance from latent heat to sensible heat (Wilson \& Baldocchi 2000). These complex feedbacks show the acute need of further drought research in the context of global warming processes in the Mediterranean region.

Acknowledgements. This study has been supported by the research projects CGL2008-01189/BTE and CGL2006-11619/ HID, financed by the Spanish Commission of Science and Technology; FEDER, EUROGEOSS (FP7-ENV-2008-1226487) and ACQWA (FP7-ENV-2007-1-212250), financed by the VII Framework Programme of the European Commission; 'Las sequías climáticas en la cuenca del Ebro y su respuesta hidrológica' and 'La nieve en el Pirineo aragonés: Distribución espacial y su respuesta a las condiciones climáticas', financed by 'Obra Social La Caixa' and the Aragón Government; and the project INCITE09 383278 PR, financed by Xunta de Galicia.

\section{LITERATURE CITED}

Adams HD, Guardiola-Claramonte M, Barron-Gafford GA, Villegas JC and others (2009) Temperature sensitivity of drought-induced tree mortality portends increased regional die-off under global-change-type drought. Proc Natl Acad Sci USA 106:7063-7066

Andreu L, Gutiérrez E, Macia M, Ribas M, Bosch O, Camarero JJ (2007) Climate increases regional tree-growth variability in Iberian pine forests. Glob Change Biol 13: 804-815

$>$ Blenkinsop S, Fowler HJ (2007) Changes in European drought characteristics projected by the PRUDENCE regional climate models. Int J Climatol 27:1595-1610

Breshears DD, Cobb NS, Rich PM, Price KP and others (2005) Regional vegetation die-off in response to globalchange-type drought. Proc Natl Acad Sci USA 102: 15144-15148

> Brunet M, Saladié O, Jones P, Sigró J and others (2006) The development of a new dataset of Spanish Daily Adjusted Temperature Series (SDATS) (1850-2003). Int J Climatol 26:1777-1802

Cai W, Cowan T (2008) Evidence of impacts from rising temperature on inflows to the Murray-Darling basin. Geophys Res Lett 35:L07701. doi:10.1029/2008GL033390

Ciais P, Reichstein M, Viovy N, Granier A and others (2005) Europe-wide reduction in primary productivity caused by the heat and drought in 2003. Nature 437:529-533

Dai A (2011) Drought under global warming: a review. Clim Change 2:45-65

Dracup JA, Lee K, Paulson EG (1980) On the definition of droughts. Water Resour Res 16:297-302

Droogers P, Allen RG (2002) Estimating reference evapotranspiration under inaccurate data conditions. Irrig Drain Syst 16:33-45

Dubrovsky M, Svoboda MD, Trnka M, Hayes MJ, Wilhite DA, Zalud Z, Hlavinka P (2008) Application of relative drought indices in assessing climate-change impacts on drought conditions in Czechia. Theor Appl Climatol 96: 155-171

El Kenawy A, López-Moreno JI, Vicente-Serrano SM (2011) Recent changes in daily temperature extremes in northeastern Spain (1960-2006). Nat Hazards Earth Syst Sci doi:10.5194/nhess-11-1-2011

> Feyen L, Dankers R (2009) Impact of global warming on streamflow drought in Europe. J Geophys Res 114:D17116. doi:10.1029/2008JD011438

García-Ruiz JM, López-Moreno JI, Vicente-Serrano SM, Lasanta T, Beguería S (2011) Mediterranean water resources in a global change scenario. Earth Sci Rev 105: 121-139

Gavilán P, Estévez J, Berengena J (2008) Comparison of standardized reference evapotranspiration equations in southern Spain. J Irrig Drain Eng 134:1-12

Gerten D, Rost S, von Bloh W, Lucht W (2008) Causes of change in 20th century global river discharge. Geophys Res Lett 35:L20405

Giorgi F (2006) Climate change hot-spots. Geophys Res Lett 33:L08707. doi:10.1029/2006GL025734

> Giorgi F, Bi X, Pal J (2004) Mean, interannual variability and trends in a regional climate change experiment over Europe. II. Climate change scenarios (2071-2100). Clim Dyn 23:839-858

González-Hidalgo JC, Lopez-Bustins JA, Štepánek P, MartinVide J, de Luis M (2009) Monthly precipitation trends on the Mediterranean fringe of the Iberian Peninsula during the second-half of the twentieth century (1951-2000). Int J Climatol 29:1415-1429

> Guttman NB (1999) Accepting the standardized precipitation index: a calculation algorithm. J Am Water Resour Assoc 35:311-322

Hargreaves GL, Samani ZA (1985) Reference crop evapotranspiration from temperature. Appl Eng Agric 1:96-99

> Hayes M, Wilhite DA, Svoboda M, Vanyarkho O (1999) Monitoring the 1996 drought using the standardized precipitation index. Bull Am Meteorol Soc 80:429-438

> Hisdal H, Stahl K, Tallaksen LM, Demuth S (2001) Have droughts in Europe become more severe or frequent? Int J Climatol 21:317-333

Hu Q, Willson GD (2000) Effect of temperature anomalies on the Palmer drought severity index in the central United States. Int J Climatol 20:1899-1911

Ji L, Peters AJ (2003) Assessing vegetation response to drought in the northern Great Plains using vegetation and drought indices. Remote Sens Environ 87:85-98

Jump AS, Hunt JM, Peñuelas J (2006) Rapid climate changerelated growth decline at the southern range edge of Fagus sylvatica. Glob Change Biol 12:2163-2174

Lanzante JR (1996) Resistant, robust and non-parametric techniques for the analysis of climate data: theory and examples, including applications to historical radiosonde station data. Int J Climatol 16:1197-1226

Lehner B, Doll P, Alcamo J, Henrichs T, Kaspar F (2006) Estimating the impact of global change on flood and drought risks in Europe: a continental integrated analysis. Clim Change 75:273-299

> Lespinas F, Ludwig W, Heussner S (2009) Impact of recent climate change on the hydrology of coastal Mediterranean 
rivers in southern France. Clim Change 99:425-456

Liang S, Ge S, Wan L, Zhang J (2010) Can climate change cause the Yellow River to dry up? Water Resour Res 46: W02505. doi:10.1029/2009WR007971

López-Moreno JI, Hess TM, White SM (2009) Estimation of reference evapotranspiration in a mountainous Mediterranean site using the Penman-Monteith equation with limited meteorological data. Pirineos 164:7-31

López-Moreno JI, Vicente-Serrano SM, Beguería S, GarcíaRuiz JM, Portela MM, Almeida AB (2009b) Downstream propagation of hydrological droughts in highly regulated transboundary rivers: the case of the Tagus River between Spain and Portugal. Water Resour Res 45:W02405. doi:10. 1029/2008WR007198

López-Urrea R, Martín de Santa Olalla F, Fabeiro C, Moratalla A (2006) Testing evapotranspiration equations using lysimeter observations in a semiarid climate. Agric Water Manag 85:15-26

Lorenzo-Lacruz J, Vicente-Serrano SM, López-Moreno JI, Beguería S, García-Ruiz JM, Cuadrat JM (2010) The impact of droughts and water management on various hydrological systems in the headwaters of the Tagus River (central Spain). J Hydrol (Amst) 386:13-26

Lorenzo-Lacruz J, Vicente-Serrano SM, López-Moreno JI, González-Hidalgo JC, Morán-Tejeda E (2011) The response of Iberian rivers to the North Atlantic Oscillation. Hydrol Earth Syst Sci Disc. doi:10.5194/hessd-8-44592011

Mariotti A, Zeng N, Yoon J, Artale V, Navarra A, Alpert P, Li L (2008) Mediterranean water cycle changes: transition to drier 21st century conditions in observations and CMIP3 simulations. Environ Res Lett 3:044001. doi:10.1088/17489326/3/4/044001

Martínez-Cob A (2002) Infraestimación de la evapotranspiración potencial con el método de Thornthwaite en climas semiáridos. In: Cuadrat JM, Vicente y SM, Saz MA (eds) La información climática como herramienta de gestión ambiental. Universidad de Zaragoza, Zaragoza, p $117-122$

Martínez-Vilalta J, López BC, Adell N, Badiella L, Ninyerola $M$ (2008) Twentieth century increase of Scots pine radial growth in NE Spain shows strong climate interactions. Glob Change Biol 14:2868-2881

McKee TBN, Doesken J, Kleist J (1993) The relationship of drought frequency and duration to time scales. In: Proc 8th Conf Appl Climatol. American Meteorological Society, Anaheim, CA, p 179-184

Mimikou MA, Hadjisavva PS, Kouvopulos YS, Afrateos H (1991) Regional climate change impacts. II. Impacts on water management works. Hydrol Sci J 36:259-270

Mitchell TD, Jones PD (2005) An improved method of constructing a database of monthly climate observations and associated high-resolution grids. Int J Climatol 25:693-712

Moreira EE, Paulo AA, Pereira LS, Mexia JT (2006) Analysis of SPI drought class transitions using loglinear models. J Hydrol (Amst) 331:349-359

Moreira E, Mexia JT, Pereira LS (2008) Assessing cycles of severe/extreme drought events using spectral analysis of precipitation time series. In: Andreassen HM (ed) New topics in water resources research and management. Nova Science Publishers, New York, p 349-361

- Nicholls N (2004) The changing nature of Australian droughts. Clim Change 63:323-326

Rodríguez-Puebla C, Encinas AH, García-Casado LA, Nieto S (2009) Trends in warm days and cold nights over the Iberian Peninsula: relationships to large-scale variables. Clim Change 100:667-684
Sheffield J, Wood EF (2007) Projected changes in drought occurrence under future global warming from multimodel, multi-scenario, IPCC AR4 simulations. Clim Dyn 31:79-105

Snoussi M, Haïda S, Imassi S (2002) Effects of the construction of dams on the water and sediment fluxes of the Moulouya and the Sebou rivers, Morocco. Reg Environ Change 3: 5-12

Sousa P, Trigo RM, Aizpurua P, Nieto R, Gimeno L, GarciaHerrera R (2010) Trends and extremes of drought indices throughout the 20th century in the Mediterranean. Nat Hazards Earth Syst Sci 11:33-51

Syed TH, Famiglietti JS, Rodell M, Chen J, Wilson CR (2008) Analysis of terrestrial water storage changes from GRACE and GLDAS. Water Resour Res 44:W02433. doi:10.1029/ 2006WR005779

Vanderlinden K, Giráldez JV, van Meirvenne M (2008) Spatial estimation of reference evapotranspiration in Andalusia, Spain. J Hydrometeorol 9:242-255

> Vicente-Serrano SM (2006a) Spatial and temporal analysis of droughts in the Iberian Peninsula (1910-2000). Hydrol Sci J 51:83-97

> Vicente-Serrano SM (2006b) Differences in spatial patterns of drought on different time scales: an analysis of the Iberian Peninsula. Water Resour Manag 20:37-60

Vicente-Serrano SM (2006c) Evaluating the impact of drought using remote sensing in a Mediterranean, semi-arid region. Nat Hazards 40:173-208

Vicente-Serrano SM, Cuadrat-Prats JM (2006) Trends in drought intensity and variability in the middle Ebro valley (NE Spain) during the second half of the twentieth century. Theor Appl Climatol 88:247-258

Vicente-Serrano SM, López-Moreno JI, Beguería S, LorenzoLacruz J, Azorin-Molina C, Morán-Tejeda E (2011) Accurate computation of a streamflow index. J Hydrolog Eng. doi:10.1061/(ASCE)HE.1943-5584.0000433

Vicente-Serrano SM, López-Moreno JI (2005) Hydrological response to different time scales of climatological drought: an evaluation of the standardized precipitation index in a mountainous Mediterranean basin. Hydrol Earth Syst Sci 9:523-533

Vicente-Serrano SM, López-Moreno JI (2006) The influence of atmospheric circulation at different spatial scales on winter drought variability through a semiarid climatic gradient in north east Spain. Int J Climatol 26:1427-1456

- Vicente-Serrano SM, González-Hidalgo JC, de Luis M, Raventós J (2004) Spatial and temporal patterns of droughts in the Mediterranean area: the Valencia region (eastern Spain). Clim Res 26:5-15

> Vicente-Serrano SM, Lasanta T, Gracia C (2010a) Aridification determines changes in leaf activity in Pinus halepensis forests under semiarid Mediterranean climate conditions. Agric For Meteorol 150:614-628

> Vicente-Serrano SM, Beguería S, López-Moreno JI (2010b) A multi-scalar drought index sensitive to global warming: the standardized precipitation evapotranspiration indexSPEI. J Clim 23:1696-1718

Vicente-Serrano SM, Beguería S, López-Moreno JI, Angulo M, El Kenawy A (2010c) A new global $0.5^{\circ}$ gridded dataset (1901-2006) of a multiscalar drought index: comparison with current drought index datasets based on the Palmer Drought Severity Index. J Hydrometeorol 11:1033-1043

Wafa TA, Labib AH (1973) Seepage losses from Lake Nasser. In: Ackermann WC, White GF, Worgthington EB (eds) Man made lakes: their problems and environmental effects. Geophys Monogr 17, American Geophysical Union, Washington, DC, p 287-291 
Walter MT, Wilks DS, Parlange JY, Schneider RL (2004) Increasing evapotranspiration from the conterminous United States. J Hydrometeorol 5:405-408

Weiß M, Flörke M, Menzel L, Alcamo J (2007) Model-based scenarios of Mediterranean droughts. Adv Geosci 12: $145-151$

> Wilson KB, Baldocchi DD (2000) Seasonal and interannual variability of energy fluxes over a broadleaved temperate

Submitted: October 28, 2010; Accepted: March 28, 2011 deciduous forest in North America. Agric For Meteorol 100:1-18

Yevjevich VM (1967) An objective approach to definition and investigation of continental hydrologic droughts. Hydrol Pap 23, University of Colorado, Boulder, CO

Yulianti JS, Burn DH (1998) Investigating links between climatic warming and low streamflow in the prairies region of Canada. Can. Wat Resour J 23:45-60

Proofs received from author(s): August 4, 2011 